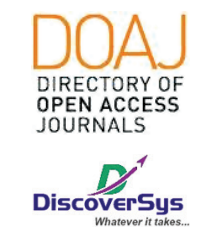

Published by DiscoverSys

\title{
Perbedaan hitung trombosit, Mean Platelet Volume (MPV), dan Platelet Distribution Width (PDW) antara pasien dengan infeksi Helicobacter pylori positif dan negatif di RSUP H. Adam Malik, Medan, Indonesia
}

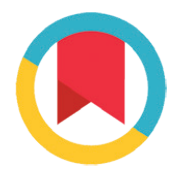

CrossMark

\author{
Fauzan Indra M. Lubis, ${ }^{1 *}$ Ricke Loesnihari, ${ }^{1}$ Taufik Sungkar ${ }^{2}$
}

\section{ABSTRACT}

Background: H. Pylori cause one of the most common human infections, being present in the gastric mucosa of more than a half of the world population. H. pylori infection can be detected by testing antibodies ( $\lg A$ and $\lg G$ ) in serum or saliva. Platelets play an important role in the pathogenesis of abnormalities associated with local or systemic inflammation through the release of thrombotic and inflammatory agents. Mean Platelet Volume (MPV) has long been known as a marker of inflammation and this role has been shown previously in various gastrointestinal disorders. Platelet distribution width (PDW) is a platelet index that reflects variations in platelet size. Methods: Thirty-two consecutive dyspepsia patient who fulfilled the criteria were included. Platelet levels, MPV, PDW, are promising in each patient. We changed the differences in platelets, MPV, PDW patients, dyspepsia with positif and negatif $\mathrm{H}$. pylori infection. Data were analyzed using SPSS version 20 for windows.

Results: Most of respondents were females (71.9\%) and 56 \pm 17.45 years old for the average age. The mean of hemoglobin level was $13.47 \pm 1.59 \mathrm{~g} / \mathrm{dL}$, followed by $11,33 \pm 1,71 \mathrm{fL}$ for MPV, $10,7 \pm 0,75 \mathrm{fL}$ for PDW, and positif H.pylori infection in 56,3\% of respondents. There were no differences in platelets, MPV, PDW significantly between the population groups of $\mathrm{H}$. pylori positif and $\mathrm{H}$. pylori negatif $(\mathrm{P}>0.05)$ Conclusion: There were no differences in platelets, MPV, PDW significantly between the population group $\mathrm{H}$. pylori positif and $\mathrm{H}$. pylori negatif.

Keywords: H. pylori, Platelets, MPV, PDW, Dyspepsia.

Cite This Article: Lubis,F..M., Loesnihari,R., Sungkar, T. 2019. Perbedaan hitung trombosit, Mean PlateletVolume (MPV), dan Platelet Distribution Width (PDW) antara pasien dengan infeksi Helicobacter pylori positif dan negatif di RSUP H. Adam Malik, Medan, Indonesia. Intisari Sains Medis 10(3): 575-579. DOl: 10.15562/ism.v10i3.466

Latar Belakang: $H$. pylori adalah penyebab paling umum dari gastritis kronis dan menginfeksi lebih dari separuh populasi dunia. Infeksi H. pylori dapat dideteksi dengan menguji antibodi (IgA dan $\mathrm{lg}$ ) dalam serum atau air liur. Trombosit memainkan peran penting dalam patogenesis kelainan yang terkait dengan peradangan lokal atau sistemik melalui pelepasan agen trombotik dan inflamasi. Mean Platelet Volume (MPV) telah lama dikenal sebagai penanda peradangan dan peran ini telah ditunjukkan sebelumnya pada berbagai kelainan gastrointestinal. Platelet distribution width (PDW) adalah indeks platelet yang mencerminkan variasi ukuran platelet. Metode: Tiga dua pasien dispepsia yang memenuhi kriteria diikutsertakan dalam penelitian ini. Kadar Trombosit, MPV, PDW, diuji pada setiap pasien. Kami menyelidiki perbedaan Trombosit,
MPV, PDW pasien dispepsia dengan infeksi $H$. Pylori positif dan negatif. Data dianalisis menggunakan piranti lunak SPSS versi 20 untuk Windows.

Hasil: Sebagian besar responden adalah perempuan $(71,9 \%)$ dan rata-rata usia responden adalah $56 \pm 17,45$ tahun. Rata-rata kadar hemoglobin adalah 13,47 $\pm 1,59 \mathrm{~g} / \mathrm{dL}$, diikuti dengan 11,33 $\pm 1,71 \mathrm{fL}$

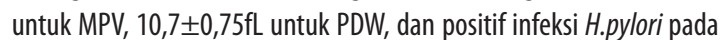
56,3\% responden. Tidak terdapat perbedaan Trombosit, MPV, PDW secara bermakna antara kelompok populasi $H$. pylori positif dan $H$. pylori negatif $(\mathrm{P}>0,05)$

Kesimpulan: Tidak terdapat perbedaan Trombosit, MPV, PDW secara bermakna antara kelompok populasi $H$. pylori positif dan $H$. pylori negatif.
Fauzan Indra M. Lubis; Departemen Patologi Klinik, Fakultas Kedokteran Universitas Sumatera Utara, RSUP H. Adam Malik, Medan, Indonesia; fauzan_indra@ymail.com

Diterima: 28-03-2019

Disetujui: 16-08-2019

Diterbitkan: 01-12-2019
Kata kunci: H. pylori, Trombosit, MPV, PDW, Dispepsia.

Cite This Article: Lubis,F...M., Loesnihari,R., Sungkar, T. 2019. Perbedaan hitung trombosit, Mean Platelet Volume (MPV), dan Platelet Distribution Width (PDW) antara pasien dengan infeksi Helicobacter pylori positif dan negatif di RSUP H. Adam Malik, Medan, Indonesia. Intisari Sains Medis 10(3): 575-579. DOl: 10.15562/ism.v10i3.466 


\section{PENDAHULUAN}

H. pylori adalah penyebab paling umum dari gastritis kronis dan menginfeksi lebih dari separuh populasi dunia. ${ }^{1}$ Bakteri ini juga terkait dengan berbagai penyakit mulai dari gastritis asimtomatik sampai ulkus gaster berat yang bisa berkembang menjadi keganasan gaster. Sejumlah laporan telah mengkonfirmasi hubungan antara kehadiran $H$. pylori pada mukosa lambung dengan peningkatan risiko karsinoma lambung. ${ }^{1}$ Beberapa penelitian seroepidemiologi juga menunjukkan bahwa adanya antibodi IgG serum terhadap $H$. pylori berhubungan dengan peningkatan risiko pengembangan penyakit tukak peptik dan tukak duodenum. ${ }^{2}$ Deteksi antibodi merupakan langkah penting dalam pengelolaan dan pencegahan komplikasi serius dari infeksi $H$. pylori. ${ }^{1,2}$ Pengukuran simultan kadar antibodi serum imunoglobulin $\mathrm{G}(\mathrm{IgG}), \mathrm{M}(\mathrm{IgM})$, dan A (IgA) terhadap H. pylori dapat digunakan untuk menentukan prevalensi infeksi akut dan kronis. ${ }^{2}$ Telah dilaporkan bahwa titer IgA dan IgG anti $H$. pylori menunjukkan adanya infeksi kronis dan terkait dengan usia.

Trombosit atau platelet merupakan unsur darah yang berfungsi menjaga homeostasis. Trombosit memainkan peran penting dalam patogenesis kelainan yang terkait dengan peradangan lokal atau sistemik melalui pelepasan agen trombotik dan inflamasi. ${ }^{3}$ Volume platelet rata-rata / Mean Platelet Volume (MPV) adalah penanda fungsi dan aktifitas platelet dimana platelet berukuran besar secara hemostatik lebih aktif. ${ }^{4}$ MPV telah lama dikenal sebagai penanda peradangan dan peran ini telah ditunjukkan sebelumnya pada berbagai kelainan gastrointestinal. Platelet distribution width (PDW) adalah indeks platelet yang mencerminkan variasi ukuran platelet. ${ }^{4}$ Penggunaan rasio platelet terhadap limfosit pun telah lama dijadikan acuan parameter hematologi untuk memprediksi respon inflamasi sistemik kronis pada keganasan. ${ }^{5}$

$H$. pylori dapat didiagnosis dengan berbagai pemeriksaan, yakni tes urease, pemeriksaan histologis, kultur, dan pemeriksaan PCR spesimen biopsi dari endoskopi. Prosedur non-invasif meliputi tes serologis untuk mendeteksi antibodi IgG terhadap H. pylori baik secara in vitro maupun in vivo dan pemeriksaan Urea Breath Test. ${ }^{2}$ Infeksi H. pylori dapat dideteksi dengan menguji antibodi (IgA dan IgG) dalam serum atau air liur. Pemeriksaan ELISA adalah metode terbaik untuk uji serologi karena sederhana, kehandalan dan biaya rendah. ELISA memiliki sensitifitas dan spesifisitas lebih dari $90 \%$. Alternatif uji lain adalah tes aglutinasi lateks, western blot dan immunochromatography. Baik aglutinasi lateks dan teknik immuno-kromatografi sering digunakan sebagai rapid diagnostic test karena mudah dilakukan. Hasil yang diperoleh bergantung pada antigen yang digunakan, usia, kelompok etnis dan kompetensi petugas laboratorium. ${ }^{6}$

Tes serologis terhadap $H$. pylori dalam penelitian epidemiologi memungkinkan kita untuk menyaring pasien yang menderita dispepsia sebelum tindakan endoskopi dan sebagai tindak lanjut jangka panjang monitoring pemberian terapi. ${ }^{7}$ Akan tetapi, disamping tes serologis, pemeriksaan darah lengkap dengan melakukan evaluasi terhadap karakteristik platelet pada pasien dengan infeksi H.pylori juga menunjukkan ciri khas tertentu. ${ }^{8}$ Namun evaluasi terhadap penanda infeksi H.pylori menggunakan parameter platelet seperti hitung platelet, MPV, dan PDW belum banyak dilakukan. Oleh karena itu, penelitian ini bertujuan untuk mengevaluasi hubungan hitung trombosit, MPV, dan PDW antara pasien dengan infeksi Helicobacter pylori positif dan negatif di RSUP H. Adam Malik, Medan, Indonesia.

\section{METODE}

Penelitian ini merupakan penelitian analitik observasional, dengan rancangan penelitian cross sectional (potong lintang) untuk mengetahui perbedaan trombosit, mean platelet volume dan platelet distribution width pada penderita helicobacter pylori positif dan negatif. Penelitian dilakukan di RSUP H. Adam Malik Medan dimulai pada bulan Oktober sampai November 2018.

Populasi target pada penelitian ini adalah penderita dengan dispepsia. Populasi terjangkau adalah penderita dengan dispepsia yang berobat ke RSUP H. Adam Malik Medan. Sedangkan sampel adalah populasi terjangkau yang memenuhi kriteria inklusi. Adapun kriteria inklusi pada penelitian ini adalah: 1) Penderita dispepsia yang berobat SMF Penyakit Dalam RSUP. H. Adam Malik dan RS USU Medan; dan 2) Tidak mendapat terapi eradikasi $H$. pylori. Sedangkan kriteria eksklusi pada studi ini adalah: 1) Pernah menjalani tindakan operasi saluran cerna, misalnya reseksi lambung; 2) Adanya penyakit keganasan lain; 3) Mendapat kemoterapi; 4) Penderita dengan riwayat penyakit autoimun; 5) Penderita dengan gangguan sistem pembekuan darah; dan 6) Penyakit infeksi akut

Dispepsia didefenisikan sebagai rasa tidak nyaman yang berasal dari daerah abdomen bagian atas, dapat berupa salah satu atau beberapa gejala berikut yaitu: nyeri epigastrium, rasa terbakar di epigastrium, rasa penuh setelah makan, cepat kenyang, rasa kembung pada saluran cerna atas, mual, muntah, dan sendawa yang bersifat nyeri kronis atau berulang.

Bahan pemeriksaan laboratorium berupa darah, serum atau plasma tanpa antikoagulan 
untuk pemeriksaan anti IgG $H$. pylori dan anti IgA H. pylori. Pemeriksaan dengan metode ELISA menggunakan alat Chemwell. Bahan pemeriksaan laboratorium berupa darah dengan antikoagulan EDTA untuk pemeriksaan trombosit, diperiksa di bawah 5 jam dengan menggunakan alat automatic cell counter analyzer Sysmex XN-1000.

Analisis data hasil penelitian disajikan dalam bentuk tabel karakteristik subjek penelitian. Perbedaan jumlah trombosit, MPV dan PDW pada penderita $H$. pylori positif dan negatif dengan menggunakan uji $\mathrm{t}$ test tidak berpasangan bila distribusi normal dan menggunakan uji Mann Whitney bila distribusi tidak normal. Seluruh data dianalisis menggunakan piranti lunak SPSS versi 20 untuk Windows.

\section{HASIL}

Pada penelitian ini diperoleh 32 subjek yang memenuhi kriteria inklusi dan eksklusi. Pada pengukuran awal di peroleh kadar minimum trombosit dengan hasil $188.000 \mathrm{mcL}$. Sedangkan kadar maksimum trombosit adalah $423.000 \mathrm{mcL}$, dengan nilai rata-rata sebesar $301.750 \pm 68.751 \mathrm{mcL}$. Kadar minimum MPV dengan hasil 8,8 fL. Sedangkan kadar maksimum MPV 11,8 fL, dengan nilai rata-rata sebesar $11,33 \pm 1,71 \mathrm{fL}$. Penelitian ini juga

\section{Tabel 1 Karakteristik Subjek Penelitian}

\begin{tabular}{lcc}
\hline Variabel & $\mathbf{N}(\%)$ & Rerata \pm SB \\
\hline Jenis Kelamin & & \\
$\quad$ Laki-laki & $9(28,1 \%)$ & \\
$\quad$ Perempuan & $23(71,9 \%)$ & $56 \pm 17,45$ \\
Umur (Tahun) & & $13.47 \pm 1,59$ \\
Hemoglobin (g/dL) & & $8.880,63 \pm 3.169,60$ \\
Leukosit (/mcL) & & $301.750 \pm 68.751$ \\
Trombosit (/mcL) & & $11,33 \pm 1,71$ \\
MPV (fL) & & $10,7 \pm 0,75$ \\
PDW (fL) & \\
Infeksi $H$. pylori & & \\
Positif & $18(56,3 \%)$ & \\
$\quad$ Negatif & $14(43,7 \%)$ & \\
\hline
\end{tabular}

Tabel 2 Analisis Hubungan Infeksi H. pylori Positif Dan Negatif dengan Trombosit, MPV Dan PDW

\begin{tabular}{lccc}
\hline & \multicolumn{2}{c}{ Infeksi H.pylori } & \\
\cline { 2 - 3 } Variabel & Positif & Negatif & Nilai p \\
\hline Trombosit & $322.111 \pm 70.442$ & $275.571 \pm 58.911$ & 0,056 \\
MPV & $9,98 \pm 0,58$ & $10,19 \pm 0,95$ & 0,448 \\
PDW & $10,99 \pm 1,29$ & $11,76 \pm 2,12$ & 0,211 \\
\hline
\end{tabular}

menemukan bahwa kadar minimum PDW yang diperoleh adalah sebesar $8,7 \%$. Sedangkan kadar maksimum PDW 15,7\%, dengan nilai rata-rata $10,7 \pm 0,75 \%$ (Tabel 1). Kemudian pada pengukuran awal diperoleh sebanyak $18(56,3 \%)$ pasien memiliki kadar $H$. pylori yang positif. Sedangkan pasien yang memiliki kadar $H$. pylori yang negatif adalah sebesar 14 (43,7\%) pasien (Tabel 1).

Uji statistic menggunakan T-Independent menunjukkan hasil tidak terdapat perbedaan trombosit yang bermakna antara kelompok populasi H. Pylori positif dan H. Pylori negatif dengan nilai $\mathrm{p}=0.056$. Tidak terdapat perbedaan MPV yang bermakna antara kelompok populasi $H$. Pylori positif dan H. Pylori negatif dengan nilai $\mathrm{p}=0.448$. Demikian juga tidak terdapat perbedaan PDW yang bermakna antara kelompok populasi $H$. pylori positif dan $H$. pylori negatif dengan nilai $\mathrm{p}=0.211$ (Tabel 2)

\section{PEMBAHASAN}

Penelitian ini melibatkan 32 pasien yang dispepsia yang memenuhi kriteria penelitian yang terdiri atas laki-laki $9(28,1 \%)$ dan perempuan 23 orang $(71,9 \%)$. Berbeda dengan hasil penelitian yang dilakukan Ali SA dkk 2017 diperoleh laki - laki dan perempuan sama banyaknya menderita infeksi H. pylori, yaitu $60(50 \%)$ laki - laki dan $60(50 \%)$ perempuan. ${ }^{8}$ Sedangkan pada penelitian Yeniova AO dkk tahun 2013 diperoleh hasil bahwa jenis kelamin perempuan lebih banyak menderita infeksi $H$. pylori, 97 (57,7\%), sedangkan laki -laki $70(60,9 \%){ }^{9}$

Usia pasien pada penelitian ini bervariasi dengan populasi termuda 23 tahun dan tertua 87 tahun, dengan rata-rata usia 56 $\pm 17,45$ tahun. Berbeda dengan penelitian yang dilakukan Ali SA dkk diperoleh rata - rata usia menderita infeksi H. pylori adalah 30,22 $\pm 1,92$ tahun. $^{7}$ Sedangkan pada penelitian Yeniova AO dkk diperoleh rata rata usia pasien yang menderita infeksi $H$. pylori adalah $40,33 \pm 13,3$ tahun. ${ }^{9}$

Pada penelitian ini diperoleh 18 (56,3\%) pasien yang memiliki kadar $H$. pylori yang positif. Sedangkan pasien yang memiliki kadar $H$. pylori yang negatif adalah $14(43,7 \%)$ orang. Berbeda dengan penelitian yang dilakukan oleh Umit $\mathrm{H}$ dkk dimana diperoleh pasien yang memiliki kadar H. pylori positif adalah sebanyak 1.701 pasien, sedangkan pasien yang memiliki kadar $H$. pylori negatif adalah 3.122 pasien. $^{10}$

Pada penelitian ini diperoleh kadar trombosit dengan $H$. pylori positif $322.111 \pm 70.442 /$ $\mu \mathrm{L}$ dan $H$. pylori negatif $275.571 \pm 58.911 / \mu \mathrm{L}$. Berbeda dengan penelitian yang dilakukan Dag 
B dkk tahun 2018 menunjukkan bahwa kadar trombosit sebelum dilakukan eradikasi $H$. pylori adalah $256.730 \pm 66.380 / \mathrm{mm}^{3}$ dan kadarnya meningkat setelah dilakukan eradikasi, yaitu 287.080 $\pm 59.240 \mathrm{~mm}^{3,11}$ Trombosit secara aktif terlibat dalam homeostasis, peradangan, imunitas dan regenerasi jaringan, proses fisiologis dan patologis lainnya. Trombosit memainkan peran penting dalam patogenesis gangguan yang terkait dengan peradangan lokal atau sistemik, agen trombotik dan inflamasi dilepaskan dari platelet dapat menyebabkan komplikasi. ${ }^{11}$

Pada penelitian ini diperoleh kadar MPV dengan $H$. pylori positif 9,98 $\pm 0,58 \mathrm{fL}$ dan $H$. pylori negatif 10,19 $\pm 0,95 \mathrm{fL}$. Penelitian Dag B dkk, kadar MPV sebelum dilakukan eradikasi $H$. pylori adalah $9.53 \pm 1.63 \mathrm{fL}$ dan kadarnya menurun setelah dilakukan eradikasi yaitu $8.61 \pm 1.48 \mathrm{fL} .{ }^{11}$ Sedangkan pada penelitian yang dilakukan Ali SA dkk di peroleh jumlah trombosit, PDW secara statistik menurun secara bermakna, disisi lain MPV ditemukan dengan kadar yang lebih tinggi pada pasien infeksi $H$. pylori dibandingkan dengan kelompok kontrol yang sehat dengan nilai $\mathrm{p}=0,03,0,01$ dan $0,00 .{ }^{8}$ Volume trombosit rata-rata (MPV) adalah penanda aktivas fungsi platelet dan aktivasi, trombosit besar adalah secara proses hemostatik lebih aktif. MPV telah lama dikenal sebagai penanda peradangan dan perannya telah ditunjukkan sebelumnya dalam berbagai kelainan gastrointestinal, sedangkan (PDW) mencerminkan bagaimana ukuran platelet. ${ }^{8}$

Kadar PDW dengan H. pylori positif 10,99 $\pm 1,29$ dan $H$. pylori negatif $11,76 \pm 2,12$. Sesuai dengan penelitian yang dilakukan Fadellala dkk tahun 2018, dimana didapatkan hasil PDW yang positif $H$. Pylori $10,03 \pm 1,09 \%$ dengan PDW kontrol $11,08 \pm 2,04 \% .^{12}$ PDW merupakan indikasi variasi dalam ukuran trombosit yang dapat menjadi tanda trombosit aktif. PDW adalah alat yang cukup baik untuk membedakan trombositemia esensial (PDW meningkat) dari trombositosis reaktif (PDW normal). PDW adalah kurva distribusi trombosit yang diukur pada tingkat $20 \%$ relatif tinggi dalam kurva distribusi ukuran trombosit, dengan total tinggi kurva 100. PDW langsung mengukur variabilitas ukuran trombosit, perubahan dengan aktivasi trombosit, dan mencerminkan heterogenitas indikasi morfologi platelet variasi dalam ukuran trombosit yang dapat menjadi tanda trombosit aktif. ${ }^{12}$

Uji statistik T Independent menunjukkan tidak terdapat perbedaan trombosit yang bermakna antara kelompok populasi $H$. pylori positif dan $H$. pylori negatif dengan nilai $\mathrm{p}=0.056$. Tidak terdapat perbedaan PDW yang bermakna antara kelompok populasi $H$. pylori positif dan $H$. pylori negatif dengan nilai $\mathrm{p}=0.211$. Demikian juga tidak terdapat perbedaan MPV yang bermakna antara kelompok populasi $H$. pylori positif dan H. pylori negatif dengan nilai $\mathrm{p}=0.448$. Berbeda pada penelitian yang dilakukan Ali SA dkk 2017 di peroleh jumlah trombosit, PDW secara statistic menurun secara bermakna, disisi lain MPV ditemukan dengan kadar yang lebih tinggi pada pasien infeksi $H$. pylori dibandingkan dengan kelompok kontrol yang sehat dengan nilai $\mathrm{p}=0,03,0,01$ dan $0,00 .^{8}$

Sedangkan pada penelitian yang dilakukan Yeniova AO dkk 2013 diperoleh nilai rata-rata MPV pada pasien dengan infeksi $H$. pylori adalah $8.57 \pm 0,94$, nilai rata-rata MPV pada pasien tanpa infeksi $H$. pylori adalah $8.53 \pm 0,92 .{ }^{9}$ Tidak ditemuan perbedaan bermakna antara kedua kelompk $\mathrm{p}>0,05$.

\section{SIMPULAN}

Hasil penelitian ini menunjukkan tidak terdapat perbedaan bermakna antara Trombosit, MPV dan PDW terhadap kelompok dengan $H$. pylori positif dan negatif. Selain itu terdapat kecenderungan bahwa pasien dispepsia yang terinfeksi $H$. pylori lebih banyak dibanding yang tidak terinfeksi H. pylori meskipun tidak bermakna secara statistik. Berkaitan dengan hal tersebut maka pemeriksaan serologi dengan menggunakan kombinasi Ig $\mathrm{G}$ anti H. Pylori dan Ig A anti H. pylori dapat dipergunakan sebagai skrining yang baik untuk pemeriksaan H. pylori.

\section{ETIKA PENELITIAN}

Penelitian ini dilaksanakan setelah mendapat izin dari Komite Etik Penelitian Kesehatan Fakultas Kedokteran Universitas Sumatera Utara.

\section{KONFLIK KEPENTINGAN}

Tidak terdapat konflik kepentingan dalam penulisan laporan hasil penelitian ini

\section{PENDANAAN}

Penulis bertanggung jawab terhadap pendanaan penelitian tanpa melibatkan pihak sponsor, grant, atau sumber pendanaan lainnya.

\section{KONTRIBUSI PENULIS}

Seluruh penulis memiliki kontribusi yang sama dalam penelitian ini baik dari tahap perencanaan, pengambilan data, analisis data penelitian, hingga interpretasi data penelitian. 


\section{DAFTAR PUSTAKA}

1. Watari J, Chen N, Amenta PS, Fukui H, Oshima T, Tomita $\mathrm{T}$, et al. Helicobacter pylori associated chronic gastritis, clinical syndromes, precancerous lesions, and pathogenesis of gastric cancer development. World J Gastroenterol. 2014;20(18):5461-73.

2. Montazer-Saheb S, Farajnin S, Saeedi N, Yousefzadeh R, Rafat A, Rahbarnia L. Seroprevalence of Helicobacter pylori infection in patients suffering from gastric symptoms in the Northwest of Iran. African Journal of Microbiology Research. 2011;5(22):3616-3619.

3. Thomas MR, Storey RF. The role of platelets in inflammation. Thromb Haemost. 2015;114(3):449-58.

4. Noris P, Melazzini F, Balduini CL. New roles for mean platelet volume measurement in the clinical practice? Platelets. 2016;27(7):607-612.

5. Prabawa IPY, Bhargah A, Liwang F, Tandio DA, Tandio AL, Lestari AAW, et al. Pretreatment Neutrophilto-Lymphocyte ratio (NLR) and Platelet-to-Lymphocyte Ratio (PLR) as a Predictive Value of Hematological Markers in Cervical Cancer. Asian Pac J Cancer Prev. 2019;20(3):863-868.

6. Khan GA, Jaleel S, Riaz S, Suleman BA. Evaluation of the diagnostic accuracy of serology test kit for detection of H.Pylori infection in patients presenting with non-ulcer dyspepsia taking histopathology as gold standard. Pakistan Journal of Pathology. 2010;21(2):55-60.

7. Pandya HB, Patel JS, Agravat HH, Singh NK. NonInvasive Diagnosis of Helicobacter pylori: Evaluation of Two Enzyme Immunoassays, Testing Serum IgG and IgA Response in the Anand District of Central Gujarat, India. Journal of Clinical and Diagnostic Research. J Clin Diagn Res. 2014;8(6):DC12-5.
8. Ali SA, Gaufri NEAM. Platelet Characterization in Helicobacter Pylori Patients. Open Access Library Journal. 2017;4(8):1-6.

9. Yeniova AO, Kucukazman M, Ata M, Dal K, Kefeli A, Bulus $H$, et al. 2013. Investigation of the association between mean platelet volume and Helicobacter pylori gastritis. African Journal of Microbiology Research. 2013;7(20):2179-2183.

10. Umit H, Umit EG. Helicobacter pylori and mean platelet volume: a relation way before immune thrombocytopenia?. Eur Rev Med Pharmacol Sci. 2015;19(15):2818-23.

11. Dag B, Umii EG, Umit H. Variations in Mean Platelet Volume in Patients with Helicobacter pylori Infection before and after Eradication, Way before Immune Thrombocytopenia?. Proceedings. 2018;2(9):1-4

12. Fadellala MH, Elnager A, Elkhair MK, Mohammed MN. Effect of $\mathrm{H}$. pylori Infection on Hematological Parameter among Patient with $\mathrm{H}$. pylori Infection at Atbara City 2017. Advancements Bioequiv Availab. 2018;2(2):1-7

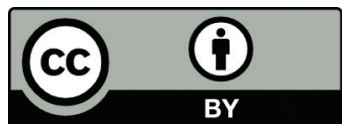

This work is licensed under a Creative Commons Attribution 